\title{
Pinar Üre, Reclaiming Byzantium: Russia, Turkey and the Archae- ological Claim to the Middle East in the 19th Century, London, I.B. Taurus 2020, 212 p., e-PDF: 978-1-7883-1746-7
}

Nicolae Roddy*

This book offers a well-researched and objective study of the mission and activities of the Russian Archaeological Institute in Constantinople (Russkii Arkheologicheskii Institut $v$ Konstantinople), RAIC hereafter, set against the backdrop of political intrigue during the waning decades of the Ottoman Empire. Its author draws from a vast wealth of primary sources - Turkish and Russian official government documents; formerly secret files from various Ottoman ministerial archives; diplomatic and personal correspondence; and materials from the Russian Academy of Sciences, the Russian State Historical Archive, and the RAIC's own professional journal, Isvestiia - all of which evidence the conclusion that the RAIC's goals, aspirations, and activities were motivated less by the science of archaeology than by a pan-Slavic historical revisionism aimed at assembling material reification of imperial Russia's self-perception as the true inheritors of Byzantium. This ideology primarily championed by theologians and clergy of the Russian Orthodox Church, but also among the literati, most notably Fyodor Dostoyevsky, whose influence inspired the populace to herald Russia's role in maintaining the Kingdom of God on earth, leading to the the phenomenon of Russian messianism.

The book introduces its subject within the context of nineteenth-century archaeological exploration. With appropriate nuance and fine detail, its author contrasts the usual nationalist, colonialist, and imperialist models, and then shows how Russia's involvement with the Ottoman Porte differs - most notably in the fact that we see here a commercial, diplomatic, and cultural exchange between two strong neighboring empires, which had been negotiating uneasy relations with one another for almost half a millennium. The author then begins unweaving the fabric of late nineteenth-century scientific and political intrigue, exposing the RAIC's role as a Russian "softpower" foreign policy tool that focused on Byzantine, Slavic, and Orthodox antiquities in the Empire as a means of nourishing imperial Russian identity and interests vis-à-vis Byzantium.

Chapter one begins by situating the establishment of the RAIC within the context of nineteenth-century Russian scholarly interests in Byzantinology. The life of the Institute arises from the vision of Fyodor

\footnotetext{
* Nicolae Roddy, PhD, Professor of Theology, Dowling Hall Humanities Building 133, Creighton University, Omaha, NE 68178 USA, nicoroddy@gmail.com.
} 
Ivanovich Uspenskii, an accomplished Byzantinologist and the Institute's director from its founding in 1895, until 1914, when the outbreak of war forced it to close. Uspenskii represented many Russian intellectuals of his day, who championed the conviction that Byzantium had been the valiant defender of western civilization and that it was up to Russia, with Moscow as Third Rome, to take up the cause. According to Uspenskii and many other scientists of his day, the seeds of Russian culture were self-evident all along the Balkan edge of the Black Sea and elsewhere, having germinated along with the flourishing of Prince Vladimir's greater Rus to embrace, embody, and inherit the symbols and ideals of Byzantium - selectively irrespective of Byzantium's actual Hellenic origins and identity.

Chapter two is of special interest in that it offers a thoroughly documented assessment of Ottoman archaeology transformation from national disinterest to the establishment of its own archaeological agencies and administrations. During the pro-western cultural renovation of the Tanzimat period (1839-1876), Ottoman intellectuals began to adopt western scientific methodologies, while the Porte was beginning to notice the relationship between cultural property and national sovereignty arising from the competition of western nations over archaeological exploration within its own territories. This competition was largely defensive from the Ottoman side of things, for, according to the author, Ottoman culture had no coherent historical narrative of its own, only a need to defend its sovereignty from foreign involvement. The Ottoman cultural representative, its own equivalent of the RAIC's Uspenskii, was Osman Hamdi Bey, director of the Imperial Museum and one of Turkish archaeology's founders.

The book goes on to describe the establishment of the RAIC and the Imperial Orthodox Palestine Society, and their complex relationships among other Russian imperial offices and agencies. Both institutions were actively involved in the recovery and documentation of Byzantine material remains with an eye toward the reification of Russia's self-perception as the ongoing embodiment of Byzantium, but while the latter was equally invested in recovering the material world of the Bible, the RAIC continued to focus its expeditions around the Black Sea with an eye toward fulfillment of national and cultural aspirations, especially on the Crimean peninsula, the celebrated location of Prince Vladimir's baptism. At the same time, the complex intrigues among the Balkan kingdoms, especially between Serbia and Bulgaria, are covered in a concise but thorough way, including the RAIC's failure to forge pan-Slavic alliances by adding a Slavic Department.

The remainder of the book, up until the final chapter, details the many RAIC projects around the Black Sea and concomitant political implications 
in dealing with Ottoman authorities up to the brink of the Great War. These projects began on the northern coast of Turkey - at Trebizond, Sinop, and Samsun - and eventually expanded to Byzantine-period sites throughout the Balkans, Asia Minor, and the Levant. These inaugural projects did not begin with systematic rigor, but gradually developed alongside Russian archaeologists' western counterparts. Many sites had been Orthodox monasteries, so in addition to conducting regular scientific activities aimed at recovering a Byzantine presence in urban settings, the RAIC conducted extensive research in the manuscripts preserved in churches and monasteries throughout the Ottoman-held Balkans, including Mount Athos, Mount Sinai, and the archives of the Orthodox Patriarchate of Constantinople. During this period, up to the brink of the Balkan War, the RAIC, led by Uspenskii, carried out its ideological mission with relative independence from the Russian government, at the same time continuing to negotiate its own path vis-à-vis the Porte and its Imperial Museum, led by Hamdi. This path was "characterized by a combination of cooperation and conflict" (113). With the outbreak of the Balkan War, archaeological research became fragmented, as efforts inspired by pan-Slavism and unified Orthodoxy were thwarted by political conflict and concerns.

The book concludes with a look at the closing days of the RAIC at the outbreak of the First World War. For Russian monarchists, the hope was that Istanbul would be captured and occupied by the Russians, bringing to greater realization the dream of Russia's ascent to the see of St. Andrew, Russia's patron saint, and the restoration of Hagia Sophia to a church. Apparently, Russia's aspirations were not opposed by the great western powers, but came to be thwarted by its own political upheavals. The RAIC's final archaeological expedition was conducted in and around Trebizond, which was already under Russian military control, with an eye toward preservation of its rich Christian and Muslim monuments, although plans for the latter involved eventually restoring them to Byzantine-style churches. According to the author, this "preservation" was observed by some, especially local Greeks, to be nothing less than looting, as loads of artifacts continued to be shipped to Russian museums and storehouses (135).

As one might expect, the great ideological transformations that took place as a result of the political upheavals in the Russian and Ottoman empires affected the role of archaeology for both. It is a well-known fact that Tsarist Russia sought to link itself historically to Byzantium as the new protector of Orthodoxy, while Ottoman archaeologists, according to the author, were less interested in Hellenistic-Roman and Late Roman (i.e., Byzantine) monuments than the territories in which these monuments were located 
(144). At any rate, in May of 1920, the communist regime officially abolished the RAIC and replaced it with the Academy of Material Culture, which among other things established a program of repatriation of the looted artifacts with Turkey's new republican regime. At the same time, Uspenskii's hope that the RAIC would be revived died on the vine, along with Tsarist Russia's vision for Byzantine-style political and ecclesiastical leadership over a much wider, pan-Slavic Orthodox realm.

The book offers a thoroughly researched, well organized, and highly readable examination of imperial Russia's involvements in recovering the material culture of Byzantium during the waning years of the Ottoman Empire. The ideological motivations and cultural biases that influenced and guided these scientific endeavors, especially evident in the mission of the RAIC in the Balkans, are treated as matters of fact, and there is no hint of interpretation or judgment on the part of the author. The book exemplifies the highest quality scholarship in carrying out exactly what it sets out to do. In addition to its roughly 150 pages of text, the book contains over thirty pages of notes, a fifteen-page bibliography, and a number of leading sources for further reading.

\section{Conclusion}

How might this book be timely and important beyond its valuable, self-defined limits? On the basis of this reviewer's twenty-year tenure as co-director and area supervisor of an archaeological dig nestled at the foot of the Golan Heights, I have often had to give serious consideration to the intersection of archaeology, cultural ideology, and politics in a region still regarded by many as occupied territory more than half a century after the fact. The modern nation state's claims on Palestinian territories all but ignores two thousand years of history in order to forge religious and cultural continuity with biblical Israel, which it then exploits for further nationalistic and economic purposes. By contrast, it should not be surprising that Palestinians view Israeli Jews primarily as sons and daughters of European Zionist interlopers with no legitimate claim to Palestinian lands beyond those sanctioned by modern jurisprudential process. Although there are many obvious differences between Israel's situation and Tsarist Russia's attempt to go beyond its borders to raise Byzantium from the grave, in both cases the science of archaeology and (mis)representations of the past are co-opted for sociopolitical and economic purposes.

The resurgence of nationalism and the concomitant rise of autocratic strongmen throughout the world requires proponents of democratic principles, especially critical thinking, to recognize its methods. Nationalism re- 
quires a coherent supporting narrative of the past that is more contrived than historical - in other words, a foundational myth that provides relevancy to the thoughts and actions of the moment. In most cases, the sacred power inherent in traditional religious symbolism is co-opted, for which history offers many notable examples. Leni Riefenstahl's "Triumph of the Will” made of Hitler a kind of Odin-Christ, a superhuman deliverer for resurrecting a fallen nation baptized in fire. Romania's own Legion of St. Michael benefitted greatly as an ultra-nationalist movement by hijacking Orthodox Christian symbols and exploiting the sacred energy of the Orthodox Church's tradition and values. Nowadays, American white supremacists also identify with racialized forms of Asatruistic religion of pre-Christian central Europe, variously known as Odinism, or Wotanism, or tout some brand of Christian identity, even Orthodox Christianity, which comprises less than one-half of one percent of all Americans.

In conclusion, by co-opting religion, nationalism displays a rejection of actual historical, sociopolitical, and economic factors in order to rely on the support of selective and forced interpretations of archaeological and textual data. The science of archaeology and the critical methods of the Humanities are not antithetical to religious belief, but challenge religious persons and congregations to remain honest and alert to those who would seek to subvert the historical sciences for ideological or political gain. Although not a part of its agenda, Urë's book serves as a reminder that genuine love for, and celebration of one's own religious or national traditions demand sustained and rigorous self-critical examination. 